\title{
ANALISIS EFISIENSI KINERJA RANTAI PASOK IKAN TUNA PADA CV. TUAH BAHARI DAN PT. NAGATA PRIMA TUNA DI BANDA ACEH
}

\author{
Performance Efficiency Analysis of Tuna Fish Supply Chain at CV. Tuah Bahari \\ and PT. Nagata Prima Tuna in Banda Aceh
}

Oleh:

\author{
Teuku Athaillah ${ }^{*}$, Ahmad Humam Hamid ${ }^{2}$, Indra ${ }^{3}$ \\ 1 Universitas Teuku Umar, Meulaboh Aceh Barat. athaillah.teuku@gmail.com \\ 2Magister Agribisnis, Universitas Syiah Kuala, Banda Aceh. humamhamid@yahoo.com \\ 3Magister Agribisnis, Universitas Syiah Kuala, Banda Aceh.indrazainun@unsyiah.ac.id \\ *Korespondensi: athaillah.teuku@gmail.com
}

Diterima: 13 Maret 2017; Disetujui: 5 Oktober 2018

\begin{abstract}
Tuna fish is one of the easily perishable consumed food. Therefore before it reaches the consumers a well-designed and well-prepared supply management system is required The objectives of the research are to analyze the product, financial and information flows of tuna fish chain of supply in Banda Aceh through analyzing the performance efficiency of tuna fish supply chain performance at CV Tuah Bahari and PT Nagata Prima Tuna in Banda Aceh. Descriptive analysis is the method used to analyze the product, financial and information flows. Supply Chain Operation Reference (SCOR). Is the method used to measure the supply chain performance efficiency. SCOR preceded with hierarchy preparation based on the SCOR process, i.e. plan, source, make, delivery and return with common dimensions i.e. reliability, responsiveness, flexibility, cost and asset. The supply chain performance efficiency measurement in this research is also supported by the Analytical Hierarchy Process (AHP) and Objective Matrix (OMAX) methods The result of the research pointed out that the tuna fish product and information flow at CV Tuah Bahari and PT Nagata Prima Tuna is not optimal yet, while the financial flow is optimal. In the outcome of CV Tuah Bahari performance efficiency, $4 \mathrm{KPI}$ (Key Performance Indicator) is at Poor category, while at PT Nagata Prima $9 \mathrm{KPI}$ are categorized as Poor. The total performance value of the company is at Average category, with total index value of 62.9 and PT Nagata Prima Tuna 52.7.
\end{abstract}

Keywords: performance efficiency, SCOR, supply chain, tuna fish

\begin{abstract}
ABSTRAK
Ikan tuna tergolong bahan pangan yang memiliki karakteristik mudah rusak. Oleh karena itu, untuk sampai ke konsumen diperlukan suatu sistem manajemen rantai pasok yang baik dan memadai. Tujuan penelitian ini adalah untuk menganalisis aliran produk, aliran keuangan dan aliran informasi pada rantai pasok ikan tuna di Banda Aceh, dengan menganalisis efisiensi kinerja rantai pasok ikan tuna pada CV. Tuah Bahari dan PT Nagata Prima Tuna di Banda Aceh. Metode yang digunakan untuk menganalisis aliran produk, aliran keuangan, dan aliran informasi adalah analisis deskriptif. Metode yang digunakan untuk mengukur efisiensi kinerja rantai pasok adalah Supply Chain Operation Reference (SCOR). SCOR diawali dengan pembuatan hierarki awal yang didasarkan pada proses dalam SCOR, yaitu plan, source, make, delivery, dan return dengan
\end{abstract}


dimensi umum, yaitu reliability, responsiveness, flexibility, cost, dan asset. Pengukuran efisiensi kinerja rantai pasok dalam penelitian ini juga didukung dengan metode Analytical Hierarchy Process (AHP) dan Objective Matrix (OMAX). Hasil penelitian menunjukkan bahwa aliran produk dan aliran informasi rantai pasok ikan tuna di CV. Tuah Bahari dan PT. Nagata Prima Tuna belum optimal, sedangkan aliran keuangan sudah optimal. Hasil pengukuran efisiensi kinerja CV. Tuah Bahari, 4 KPI (Key Performance Indicator) berada pada kategori Poor, sementara pada PT Nagata Prima Tuna terdapat $9 \mathrm{KPI}$ berada pada kategori Poor. Total nilai performansi kedua perusahaan berada pada katagori Average, dengan nilai Index Total CV. Tuah Bahari 62,9 dan PT. Nagata Prima Tuna 52,7.

Kata kunci: efisiensi kinerja, $S C O R$, rantai pasok, ikan tuna

\section{PENDAHULUAN}

Perairan Aceh memiliki potensi sumber daya kelautan dan perikanan yang cukup besar. Potensi sumber daya kelautan dan perikanan yang besar menjadikan sektor ini sebagai tulang punggung perekonomian masyarakat Aceh, yang dapat mendukung sektor perindustrian dan perdagangan. Hal tersebut menjadikan Aceh memiliki beraneka ragam hasil tangkapan nelayan yang di pasok ke industri pengolahan dan diolah menjadi beragam jenis produk yang dipasarkan hingga sampai ke konsumen akhir. Salah satu potensi sumber daya kelautan di Aceh yang memiliki nilai jual yang sangat tinggi adalah ikan tuna. Harga jual ikan tuna bisa mencapai puluhan sampai ratusan ribu rupiah perkilogram dengan bobot ikan tuna bisa mencapai lebih dari seratus kilogram. Harga ikan tuna yang tinggi berpengaruh terhadap kesejahteraan dan penghasilan nelayan. Ikan tuna termasuk bahan pangan yang mudah mengalami kerusakan sehingga memerlukan penanganan yang khusus untuk mempertahankan mutunya. Proses kerusakan ikan berlangsung lebih cepat pada suhu dan kelembaban harian yang tinggi. Kerusakan mutu tersebut akan semakin cepat terjadi apabila cara penanganan ikan setelah ditangkap kurang baik, fasilitas sanitasi yang tidak memadai, serta terbatasnya sarana distribusi pemasaran.

Industri perikanan memiliki keunikan pada ikan sebagai bahan baku yang tersedia secara alami dan dapat diakses oleh manusia. Ikan jauh lebih perishable sehingga perlu penanganan logistik yang lebih kompleks serta biaya yang sangat mahal, terutama untuk yang penyimpanan yang memerlukan alat pendingin tersendiri (Batubara et al. 2017). Terdapat 2 perusahaan yang bergerak dibidang pengolahan dan pemasaran tuna di Banda Aceh yaitu PT. Nagata Prima Tuna dan CV. Tuah Bahari. Perusahaan tersebut membeli ikan tuna dari nelayan kemudian diolah, dibekukan dan selanjutnya dipasarkan. Data BPS Kota Banda Aceh 2014 PT. Nagata Prima Tuna dan CV. Tuah
Bahari mengekspor $454.421,6$ ton ikan tuna keluar negeri.

Pengukuran efesiensi kinerja supply chain memiliki peranan penting untuk mengetahui kondisi perusahaan, apakah mengalami penurunan atau peningkatan serta perbaikan apa yang harus dilakukan untuk meningkatkan kinerja perusahaan tersebut (Sufa et al. 2016). Efesiensi kinerja bisa meningkatkan penerimaan dan keuntungan perusahaan yang berpengaruh terhadap daya beli perusahaan terhadap nelayan. Penelitian mengenai rantai pasok seharusnya sudah menjadi fokus perusahaan karena rantai pasok merupakan urat nadi kelancaran bisnis perusahaan. Hal ini disebabkan karena rantai pasok perusahaan adalah sistem yang menghubungkan antara pemasok, perusahaan dan pelanggannya (Harisnanda et al. 2012). Wuwung (2013) mengatakan Rantai pasok menggambarkan seluruh proses dan kegiatan yang bertujuan menyampaikan produk kepada konsumen. Pemasok yang tidak dikelola dengan baik berdampak pada keterlambatan pengadaan bahan baku bagi perusahaan. Ruteri dan Qi yu (2009) mengatakan bahwa di dalam manajemen rantai pasok industri pangan sangat dibutuhkan relasi yang kuat antar anggota. Kunci tingkat kinerja dari perusahaan multinasional terletak pada kemampuan perusahaan bekerja sama dengan para mitra bisnisnya (Budiman 2013).

Dania et al. (2012) mengatakan dalam sebuah perusahaan, pengukuran kinerja diperlukan untuk menyediakan suatu pendekatan terstruktur yang terfokus pada rencana strategis, tujuan, dan performansi. Menurut Dinata et al. (2014) manajemen rantai pasok sendiri dianggap sebagai faktor penting bagi perusahaan untuk dijadikan sebagai keuntungan kompetitif. Setiap pelaku bisnis akan berupaya semaksimal mungkin untuk meningkatkan produktivitas, efisiensi, pelayanan yang cepat, mudah dan terus menciptakan berbagai inovasiinovasi baru untuk tetap dapat unggul dan bertahan di pasar (Ndiba et al. 2016). 
Kinerja rantai pasok merupakan hasil dari berbagai upaya yang dilakukan setiap anggota rantai pasok untuk memenuhi tujuan akhir rantai pasok, yaitu kepuasan konsumen (Sari et al. 2014). Aspek penting dalam pengembangan kluster industri adalah aspek rantai pasok, kelembagaan dan pasar (Nurani et al. 2014). Beberapa hal yang harus diperhatikan dari pelayanan konsumen adalah tingkat pemenuhan pesanan (order fill rates), ketepatan waktu pengiriman (on-time deliverer) dan tingkat pengambilan produk oleh konsumen (Subroto et al. 2015).

Salah satu faktor yang berperan penting dalam penentuan proses pengendalian mutu adalah rantai pasok (supply chain) yang merupakan proses distribusi barang, mulai dari produksi ikan di atas kapal hingga produk diterima perusahaan. Penanganan produk pada masing-masing tahap ini merupakan titik kritis yang akan menentukan mutu produk tuna loin ketika produk tersebut sampai di perusahaan dan dilakukan proses sortasi mutu (grading) (Jati et al. 2014).

Perusahaan pengolah ikan tuna sangat tergantung pada hasil tangkapan nelayan, sementara hasil tangkapan nelayan sendiri sangat bergantung pada kondisi iklim dan cuaca, keberhasilan tangkapan, dan keberadaan ikan tuna. Perusahaan mendapatkan bahan baku ikan tuna hanya dari nelayan. Berbeda dengan rantai pasok produk lainnya seperti kelapa sawit, dimana perusahaan menanam kelapa sawit pada kebun sendiri. Oleh sebab itu, rantai pasok ikan tuna sangat bergantung pada faktor eksternal dari perusahaan dan sangat tergantung dari nelayan.

Penelitian ini bertujuan untuk menganalisis aliran produk, keuangan, dan informasi pada rantai pasok ikan tuna di Banda Aceh. Selain itu bertujuan pula untuk menganalisis efisiensi kinerja rantai pasok ikan tuna pada CV. Tuah Bahari dan PT. Nagata Prima Tuna di Banda Aceh.

\section{METODE}

Penelitian dilakukan di PT. Nagata Prima Tuna yang berada di Ulee Iheu Banda Aceh dan CV. Tuah Bahari yang berada di Lampulo Banda Aceh. Objek dalam penelitian ini adalah pihak-pihak yang terlibat dalam rantai pasok ikan tuna yaitu nelayan yang menghasilkan ikan tuna, serta PT. Nagata Prima dan CV Tuah Bahari. Waktu penelitian yaitu Juni 2016 hingga Desember 2016.

Data yang digunakan dalam penelitian ini adalah data primer dan sekunder. Data primer yang digunakan antara lain data hasil wawancara dengan nelayan, pihak perusahaan dan para Ahli untuk menentukan Key Performance Indicator (KPI) dan data hasil penyebaran kuisioner untuk menentukan bobot dari KPI. Data sekunder diperoleh dari data series perusahaan PT. Nagata Prima Tuna dan CV. Tuah Bahari. Data sekunder yang digunakan antara lain data pembelian ikan tuna dari nelayan, data pembelian ikan tuna dari toke bangku, data penjualan dan ekspor tuna, data waktu pembelian tuna dan lain-lain.

Teknik pengambilan sampel dalam penelitian ini menggunakan probability dan non probability sampling. Teknik non probability sampling digunakan untuk menjawab tujuan pertama, sedangkan teknik probability sampling digunakan untuk menjawab tujuan kedua. Teknik probability sampling yang digunakan adalah cluster sampling, sedangkan teknik non probability sampling yang digunakan adalah teknik snowball sampling.

Mendenhall et al. (1978) dalam Yusuf (2014) menyatakan bahwa cluster sampling adalah simple random sampling dimana tiaptiap unit dikumpulkan sebagai satu kumpulan atau cluster. Adapun cluster yang dibuat adalah dengan memisahkan antara nelayan yang menargetkan ikan tuna sebagai hasil tangkapan (15 sampel), nelayan yang tidak menargetkan ikan tuna sebagai hasil tangkapan dengan memancing ikan tuna di sela-sela pemancingan ikan biasa (15 sampel), karyawan CV. Tuah Bahari (7 sampel), karyawan PT. Nagata Prima Tuna (7 sampel), toke Bangku (4 sampel), dan para ahli yang berasal dari perguruan tinggi (4 sampel). Jumlah sampel keseluruhan adalah 52 sampel.

Teknik cluster sampling dilakukan dengan menyebar kuesioner kepada 52 sampel yang dipilih tersebut. Teknik cluster sampling digunakan untuk mencari bobot Key Performance Indicator (KPI). KPI atau indikator kinerja utama adalah suatu indikator yang menyajikan serangkaian ukuran yang fokus pada aspek-aspek kinerja organisasi yang paling penting untuk keberhasilan organisasi pada saat ini dan waktu yang akan datang (Adianto et al. 2014).

KPI disusun berdasarkan hasil wawancara dengan pihak dari CV. Tuah Bahari, PT. Nagata Prima Tuna dan Para Ahli dari perguruan tinggi. Setelah KPI ditetapkan, KPI tersebut disusun dalam sebuah kuisioner, kemudian kuisioner disebarkan menurut cluster yang telah dibuat. Hasil dari kuisioner tersebut dilakukan pembobotan dengan Skala Banding Berpasangan untuk mengetahui $\mathrm{KPI}$ yang 
mana yang menjadi prioritas. Setelah dilakukan pembobotan dengan Skala Banding Berpasangan, dilakukan scoring system dengan menggunakan metode Objective Matrix (OMAX) untuk mengetahui nilai performansi dari setiap KPI pada perusahaan. Hasil dari scoring system dengan menggunakan metode Objective Matrix (OMAX) dikalikan dengan hasil dari pembobotan dengan Skala Banding Berpasangan untuk mengetahui performasi perusahaan.

Teknik non probability sampling yang digunakan adalah teknik snowball sampling. Snowball sampling digunakan untuk menganalisis aliran produk, keuangan, dan informasi dalam rantai pasok. Teknik snowball sampling dilakukan mulai dari mewawancarai nelayan, setelah didapatkan informasi kemana saja ikan tuna tersebut dipasok, kemudian dilakukan wawancara selanjutnya terhadap mata rantai selanjutnya. Aliran produk, keuangan, dan informasi pada rantai pasok ikan tuna dianalisis secara deskriptif. Untuk mengukur efisiensi kinerja rantai pasok digunakan metode SCOR (Supply Chain Operation Reference), metode ini diperkenalkan oleh Supply Chain Council (SCC) sebagai model pengukuran kinerja supply chain (Mutakin dan Hubeis. 2011). Menurut Hanugrani et al. (2011) Scoring system dilakukan dengan menggunakan metode Objective Matrix (OMAX) untuk mengetahui nilai performansi perusahaan dari setiap KPI. Berdasarkan skema OMAX, terdapat tiga bagian pada skema penilaian dengan model OMAX yaitu sangat rendah (merah), pertengahan (kuning), dan sangat bagus (hijau).

Perhitungan untuk menentukan skala tiap levelnya antara level 1 hingga 3 menggunakan

formulasi: Level $1-$ Level $2=\frac{(\text { level } 3-\text { level } 0)}{(3-0)}$

Adapun untuk menghitung skala antara level 3 hingga 10 dengan menggunakan formulasi:

Level 4 - Level $10=\frac{(\text { level } 10-\text { level } 3)}{(10-3)}$ (Avianda et al. 2014)

Pembobotan dilakukan dengan Skala Banding Berpasangan. Berikut adalah contoh matrik perbandingan berpasangan yang menggunakan pemisalan $A_{1}, A_{2}, A_{3}, A_{n}$ dimana $A_{1}, A_{2}$, $\mathrm{A}_{3}, \mathrm{~A}_{\mathrm{n}}$ adalah kriteria (plan, source, make, deliver, return).

\section{Contoh Matrik OMAX.}

\begin{tabular}{ccc}
\hline \multicolumn{3}{c}{ KPI No. } \\
\hline \multicolumn{3}{c}{ Performance } \\
& 10 & 10 \\
& 9 & 9 \\
& 8 & 8 \\
& 7 & 7 \\
& 6 & 6 \\
Level & 5 & 5 \\
& 4 & 4 \\
& 3 & 3 \\
& 2 & 2 \\
& 1 & 1 \\
& 0 & 0 \\
\hline
\end{tabular}

Sumber: Hanugrani et al. (2011)

Setelah diperoleh bobot dengan Skala Banding Berpasangan maka perlu di uji konsistensi. Rumus dari indeks konsistensi $(\mathrm{Cl} /$ Consistency Index) adalah (Pranoto et al. 2013):

$$
\mathrm{Cl}=\frac{(\lambda m a k s-n)}{(n-1)}
$$

Di mana $\lambda$ merupakan eigenvalue dan $\mathrm{n}$ adalah ukuran matriks. Eigenvalue maksimum suatu matriks tidak akan lebih kecil dari nilai $n$ sehingga tidak mungkin ada nilai $\mathrm{Cl}$ yang negatif. Nilai dari $\lambda$ maks adalah rata-rata dari hasil perkalian antara setiap priority vector dengan hasil bobot perbandingan awal setiap kriteria yang dibagi dengan priority vector. Perhitungan tersebut seperti yang dilakukan oleh Pasmawati dan Kusmindari (2013). Rumus dari rasio konsistensi CR (Consistency Ratio) dituliskan sebagai berikut (Pranoto et al. 2013):

$\mathrm{CR}=\frac{(C I)}{(R I)}$

Di mana :

CR : Consistency Ratio

$\mathrm{Cl}$ : Consistency Index

$\mathrm{RI}$ : Random Index

Nilai dari RI dapat dilihat pada Tabel 2.

Tabel 1 Matriks Perbandingan Berpasangan

\begin{tabular}{|c|c|c|c|c|c|}
\hline C & $A_{1}$ & $\mathbf{A}_{2}$ & $\mathbf{A}_{3}$ & $A_{n}$ & \\
\hline$A_{1}$ & $A_{11}$ & $A_{12}$ & $A_{13}$ & $A_{1 n}$ & Sumber : Lestiani (2011). \\
\hline $\mathrm{A}_{2}$ & $A_{21}$ & $A_{22}$ & $\mathrm{~A}_{23}$ & $A_{2 n}$ & Keterangan : $A_{1}, A_{2}, A_{3}, A_{\ldots, n}=$ \\
\hline$A_{3}$ & $A_{31}$ & $\mathrm{~A}_{32}$ & $\mathrm{~A}_{33}$ & $A_{3 n}$ & Kriteria (plan, source, make, \\
\hline$A_{n}$ & $A_{n 1}$ & $A_{n 2}$ & $A_{n 3}$ & $A_{n n}$ & deliver, retur \\
\hline
\end{tabular}


Tabel 2 Nilai dari Random Index

\begin{tabular}{cc}
\hline $\mathbf{N}$ & $\mathbf{R} \mathbf{~}$ \\
\hline 1 & 0 \\
2 & 0 \\
3 & 0,58 \\
4 & 0,90 \\
5 & 1,12 \\
6 & 1,24 \\
7 & 1,32 \\
8 & 1,41 \\
9 & 1,45 \\
10 & 1,51 \\
\hline
\end{tabular}

Sumber : Walangare et al. (2012)

Tabel 3 Sistem Monitoring Indikator Kinerja

\begin{tabular}{cc}
\hline Sistem Monitoring & Indikator Kinerja \\
\hline$<40$ & Poor \\
$40-50$ & Marginal \\
$50-70$ & Average \\
$70-90$ & Good \\
$>90$ & Exellent \\
\hline
\end{tabular}

Sumber: Rakhman et al. 2018.

Jika CR lebih besar dari 0,10 artinya terdapat $10 \%$ peluang bahwa masing-masing elemen tidak dibandingkan dengan layak. Dalam kasus ini, pembuat keputusan harus mengkaji ulang proses perbandingan yang telah dilakukan (Pranoto et al. 2013).

Setelah didapatkan suatu hasil berdasarkan analisis (Hasil OMAX dikalikan Bobot Skala Banding Berpasangan). Maka hasil tersebut diberi skor berdasarkan sistem monitoring indikator kinerja. Monitoring indikator kinerja adalah rekapan nilai pencapaian kinerja pada masing-masing indikator performansi ( $\mathrm{Da}$ rojat dan Yunitasari, 2017). Sistem monitoring indikator kinerja adalah konversi dari setiap bobot indikator kinerja kedalam interval nilai tertentu yaitu 0 sampai dengan 100 . Tabel 3 menunjukkan sistem monitoring indikator kinerja.

\section{HASIL}

Aliran fisik meliputi aliran produk secara fisik dari pemasok ke pelanggan. Aliran informasi meliputi jumlah permintaan, koordinasi jaringan rantai pasok, status pengiriman, dan informasi pembayaran. Aliran keuangan meliputi pembayaran cash maupun kredit dan jadwal pembayaran. Berikut ini adalah gambar aliran fisik, aliran keuangan, dan aliran informasi rantai pasok ikan tuna di Banda Aceh.
Pada Gambar 1 dapat dilihat ikan tuna yang berhasil ditangkap nelayan $95,9 \%$ dijual ke toke bangku (agen penampung), 1,7\% dijual kepada CV. Tuah Bahari, 2,2\% dijual kepada PT. Nagata Prima Tuna dan $0,2 \%$ ikan tuna yang ditolak CV. Tuah Bahari dilelang di TPI Lampulo. Toke bangku yang telah membeli ikan tuna dari nelayan kemudian memasok ikan tuna tersebut $4,1 \%$ ke CV. Tuah Bahari, dan 5,4\% ke PT. Nagata Prima Tuna dan $90 \%$ ikan tuna tersebut di pasok ke Medan. CV. Tuah Bahari kemudian memasok ikan tuna ke PT. Era Mandiri Cemerlang yang selanjutnya diekspor, sementara PT. Nagata Prima Tuna mengekspor loin grade bagus ikan tuna ke Anova Foods (Amerika) dan Yamashin (Korsel). Loin grade rendah dijual ke Agen Penampung.

Berdasarkan Gambar 1 dapat dilihat aliran fisik ikan tuna mengalir satu arah mulai dari nelayan kepada konsumen di dalam maupun ke luar negeri. Aliran informasi pada rantai pasok ikan tuna mengalir dua arah, dimulai dari nelayan sampai pada perusahaan eksportir dan konsumen. Sementara aliran keuangan rantai pasok ikan tuna mengalir satu arah yaitu mulai dari eksportir sampai kepada nelayan.

\section{Pembobotan dengan Skala Banding Berpasangan}

Terdapat 18 KPI (Key Performance Indicator) yang dipilih berdasarkan hasil wawan- 
cara dengan pihak perusahaan CV. Tuah Bahari dan PT. Nagata Prima Tuna. Kemudian dilakukan pembobotan terhadap $18 \mathrm{KPI}$ tersebut, pembobotan juga dilakukan pada proses inti dan dimensi pada rantai pasok ikan tuna. Berikut ini adalah tabel pembobotan dengan Skala Banding Berpasangan.

Tabel 4 menunjukkan hasil pembobotan terhadap $18 \mathrm{KPI}$ pada rantai pasok ikan tuna. Pada proses inti, bobot Source adalah bobot dengan skor paling besar (0,49 atau 49\%), yang artinya di antara proses inti yang lainnya source adalah prioritas utama. Sementara bobot yang paling kecil adalah bobot plan dengan skor hanya 0,04 atau $4 \%$ yang berarti plan tidak terlalu dibutuhkan dalam rantai pasok ikan tuna.

\section{Scoring Sistem Rantai Pasok}

Perhitungan scoring system dilakukan dengan menggunakan Objective Matrix (OMAX). Hasil scoring system untuk masingmasing perspektif SCOR dapat dilihat pada Tabel 5 hingga 10.

Pada Tabel 5 diketahui bahwa nilai scoring system Perspektif Plan pada CV. Tuah Bahari KPI P.R.1 adalah 3,33 yang berada pada zona merah dan berarti jauh dari target. Sementara KPI P.A.1 skor pencapaiannya adalah 5,9 berada pada zona kuning. Sementara pada PT. Nagata Prima Tuna nilai scoring system pada KPI P.R.1 dan P.A.1 skor pencapaian adalah 3,33 dan 3,73. Keduanya berada pada katagori merah yang berarti jauh dari target, oleh sebab itu KPI tersebut harus segera ditingkatkan performansinya.

Pada Tabel 6 dapat dilihat bahwa nilai scoring system perspektif Source yang terendah pada CV. Tuah Bahri berada pada KPI S.R.2, S.F.1 dan S.C.1 dengan skor pencapaian sebesar 2,44, 2,44 dan 3,56. Karena nilai pencapaiannya sangat jauh dan berada pada kategori merah, maka KPI tersebut harus segera diberikan tindakan perbaikan. Sedangkan scoring system perspektif source pada PT. Nagata Prima Tuna 4 KPI berada pada katagori merah yaitu KPI S.R.1, S.R.2, S.Re.1 dan S.F.1 dengan skor pencapaian sebesar 2,33, 2,4, 3,27 dan 2,33 . KPI yang berada pada katagori merah tersebut harus segera ditingkatkan performansinya.

Pada Tabel 7 dapat dilihat bahwa nilai scoring system perspektif Make yang terendah pada CV. Tuah Bahari berada pada KPI M.R.2, M.R.3 dan M.C.1 dengan skor pencapaian sebesar 5, 5 dan 4,71. KPI tersebut berada pada kategori kuning dan tetap masih perlu diberikan tindakan perbaikan untuk meningkatkan performansinya. Sedangkan scoring system perspektif Make pada PT. Nagata Prima Tuna yang terendah berada pada KPI S.R.2, S.F.1 dan S.C.1 dengan skor pencapaian sebesar 2,4, 2,4 dan 2,47. KPI yang berada pada katagori merah tersebut harus segera ditingkatkan performansinya

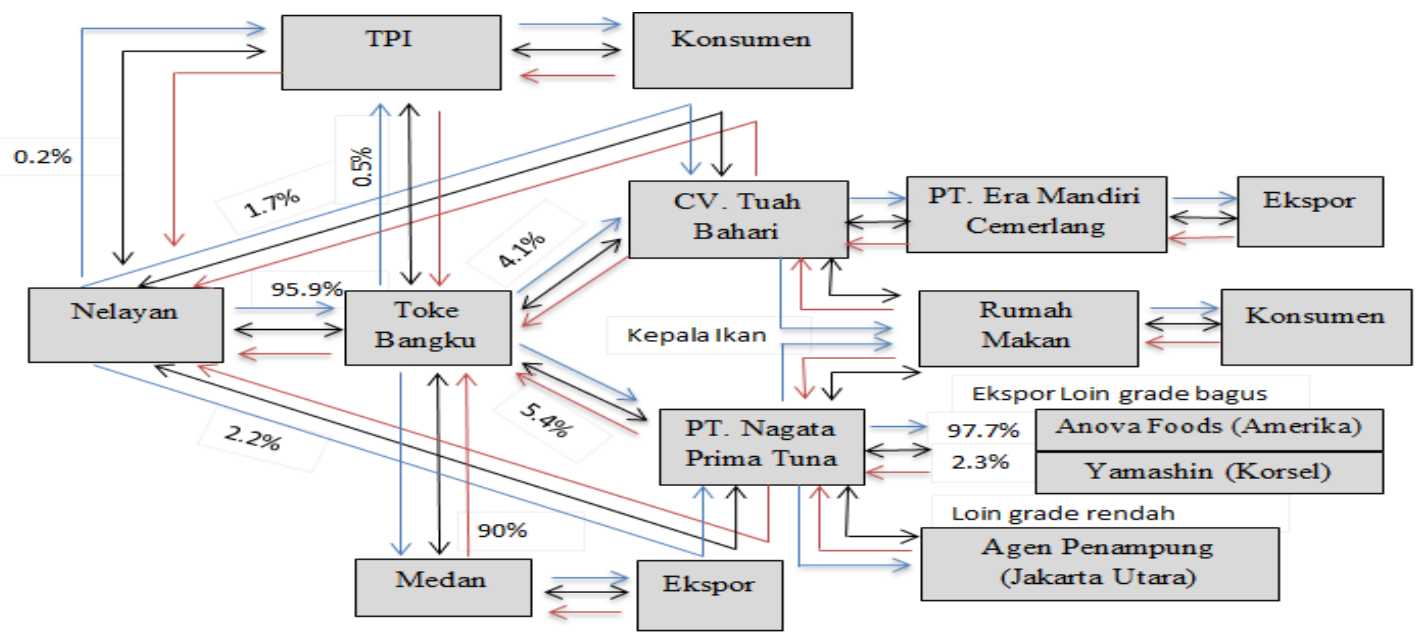

Keterangan:

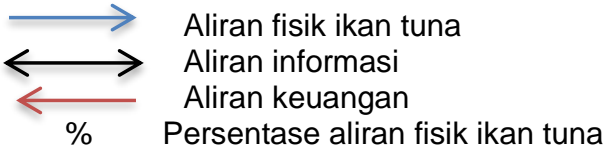

Gambar 1 Aliran Fisik, Aliran Keuangan, dan Aliran Informasi Rantai Pasok Ikan Tuna di Banda Aceh 
Tabel 4 Hasil Pembobotan dengan Menggunakan Skala Banding Berpasangan

\begin{tabular}{|c|c|c|c|c|c|c|}
\hline $\begin{array}{c}\text { Proses } \\
\text { Inti }\end{array}$ & Bobot & Dimensi & Bobot & KPI & $\begin{array}{l}\text { Key Performance } \\
\text { Indicator }\end{array}$ & Bobot \\
\hline \multirow{2}{*}{ Plan } & \multirow{2}{*}{0,04} & Reability & 0,67 & P.R 1 & Waktu mengidentifikasi & 1,00 \\
\hline & & Asset & 0,33 & P.A 1 & Cash to cash cycle time & 1,00 \\
\hline \multirow{5}{*}{ Source } & \multirow{5}{*}{0,49} & Reability & 0,30 & \multirow{3}{*}{$\begin{array}{l}\text { S.R } 1 \\
\text { S.R } 2 \\
\text { S.Re } \\
1\end{array}$} & \multirow{3}{*}{$\begin{array}{l}\text { Bahan baku yang kurang } \\
\text { bagus } \\
\text { Pemenuhan bahan baku } \\
\text { Receive product cycle } \\
\text { time }\end{array}$} & 0,75 \\
\hline & & & & & & 0,25 \\
\hline & & Responsiveness & 0,17 & & & 1,00 \\
\hline & & Flexibility & 0,10 & S.F 1 & $\begin{array}{l}\text { Supply chain flexibility and } \\
\text { adaptability }\end{array}$ & 1,00 \\
\hline & & Cost & 0,43 & S.C 1 & Cost to source & 1,00 \\
\hline \multirow{4}{*}{ Make } & \multirow{4}{*}{0,24} & & & M.R 1 & $\begin{array}{l}\text { Kesalahan dalam } \\
\text { pengepakan }\end{array}$ & 0,59 \\
\hline & & Reability & 0,33 & M.R 2 & Jumlah total produksi & 0,25 \\
\hline & & & & M.R 3 & $\begin{array}{l}\text { Jumlah Produksi } \\
\text { karyawan/Jam }\end{array}$ & 0,16 \\
\hline & & $\begin{array}{l}\text { Responsiveness } \\
\text { Cost }\end{array}$ & $\begin{array}{l}0,14 \\
0,52\end{array}$ & $\begin{array}{l}\text { M.Re1 } \\
\text { M.C } 1\end{array}$ & $\begin{array}{l}\text { Waktu produksi } \\
\text { Cost to make }\end{array}$ & $\begin{array}{l}1,00 \\
1,00\end{array}$ \\
\hline \multirow{5}{*}{ Deliver } & \multirow{5}{*}{0,15} & & & D.R 1 & Perfect condition & 0,65 \\
\hline & & Reability & 0,33 & D.R 2 & Documentation accuracy & 0,12 \\
\hline & & & & D.R 3 & Deliver cycle time & 0,23 \\
\hline & & Responsiveness & 0,14 & $\begin{array}{l}\text { D.Re } \\
1\end{array}$ & $\begin{array}{l}\text { Rata waktu pengurusan } \\
\text { dokumen }\end{array}$ & 1,00 \\
\hline & & Cost & 0,52 & D.C 1 & Cost to deliver & 1,00 \\
\hline Return & 0,07 & Reability & 1 & R.R 1 & Waranty and return & 1,00 \\
\hline
\end{tabular}

Tabel 5 Matrik Scoring System Perspektif Plan

\begin{tabular}{|c|c|c|c|}
\hline \multicolumn{4}{|c|}{ CV. Tuah Bahari } \\
\hline KPI & & P.R.1 & P.A.1 \\
\hline \multirow{11}{*}{ Level } & 10 & 1 & 8 \\
\hline & 9 & 1,33 & 8,54 \\
\hline & 8 & 1,66 & 9,08 \\
\hline & 7 & 1,99 & 9,63 \\
\hline & 6 & 2,32 & 10,17 \\
\hline & 5 & 2,65 & 10,71 \\
\hline & 4 & 2,98 & 11,25 \\
\hline & 3 & 3,31 & 11,79 \\
\hline & 2 & 3,94 & 18,7 \\
\hline & 1 & 4,57 & 25,6 \\
\hline & 0 & 5,2 & 32,51 \\
\hline \multicolumn{2}{|c|}{ Level } & 3,33 & 5,9 \\
\hline \multicolumn{2}{|c|}{ Weight } & 1 & 1 \\
\hline \multicolumn{2}{|c|}{ Value } & 3,33 & 5,9 \\
\hline
\end{tabular}

\begin{tabular}{|c|c|c|c|}
\hline \multicolumn{4}{|c|}{ PT. Nagata Prima Tuna } \\
\hline KPIN & & P.R.1 & P.A.1 \\
\hline \multirow{11}{*}{ Level } & 10 & 1 & 10 \\
\hline & 9 & 1,08 & 10,5 \\
\hline & 8 & 1,17 & 11 \\
\hline & 7 & 1,25 & 11,6 \\
\hline & 6 & 1,34 & 12,1 \\
\hline & 5 & 1,42 & 12,6 \\
\hline & 4 & 1,51 & 13,1 \\
\hline & 3 & 1,59 & 13,6 \\
\hline & 2 & 1,79 & 14,8 \\
\hline & 1 & 2 & 15,9 \\
\hline & 0 & 2,2 & 17 \\
\hline \multicolumn{2}{|c|}{ Level } & 3,33 & 3,73 \\
\hline \multicolumn{2}{|c|}{ Weight } & 1 & 1 \\
\hline \multicolumn{2}{|c|}{ Value } & 3,33 & 3,73 \\
\hline
\end{tabular}


Tabel 6 Matrik Scoring System Perspektif Source

\begin{tabular}{|c|c|c|c|c|c|c|}
\hline \multicolumn{7}{|c|}{ CV. Tuah Bahari } \\
\hline \multicolumn{2}{|c|}{ KPI No. } & S.R.1 & S.R.2 & S.Re.1 & S.F.1 & S.C.1 \\
\hline \multirow{11}{*}{ Level } & 10 & 0 & 35 & 0,74 & 100 & 37000 \\
\hline & 9 & 10 & 31,9 & 1,08 & 91,1 & 37571,4 \\
\hline & 8 & 20 & 28,8 & 1,41 & 82,2 & 38142,9 \\
\hline & 7 & 30 & 25,7 & 1,74 & 73,3 & 38714,3 \\
\hline & 6 & 40 & 22,5 & 2,07 & 64,4 & 39285,7 \\
\hline & 5 & 50 & 19,4 & 2,4 & 55,5 & 39857,1 \\
\hline & 4 & 60 & 16,3 & 2,74 & 46,6 & 40428,6 \\
\hline & 3 & 70 & 13,2 & 3,07 & 37,7 & 41000 \\
\hline & 2 & 80 & 10,2 & 4,12 & 29,1 & 42333,3 \\
\hline & 1 & 90 & 7,2 & 5,17 & 20,5 & 43666,7 \\
\hline & 0 & 100 & 4,2 & 6,23 & 11,9 & 45000 \\
\hline \multicolumn{2}{|c|}{ Level } & 10 & 2,44 & 4,11 & 2,44 & 3,56 \\
\hline \multicolumn{2}{|c|}{ Weight } & 0,75 & 0,25 & 1 & 1 & 1 \\
\hline \multicolumn{2}{|c|}{ Value } & 7,5 & 0,61 & 4,11 & 2,44 & 3,56 \\
\hline
\end{tabular}

\begin{tabular}{|c|c|c|c|c|c|c|}
\hline \multicolumn{7}{|c|}{ PT. Nagata Prima Tuna } \\
\hline KPIN & & S.R.1 & S.R.2 & S.Re.1 & S.F.1 & S.C. 1 \\
\hline \multirow{11}{*}{ Level } & 10 & 5 & 50 & 0,44 & 100 & 55000 \\
\hline & 9 & 9 & 45,3 & 0,57 & 90,7 & 56571,4 \\
\hline & 8 & 13 & 40,7 & 0,7 & 81,3 & 58142,9 \\
\hline & 7 & 18 & 36 & 0,83 & 72 & 59714,3 \\
\hline & 6 & 22 & 31,3 & 0,97 & 62,7 & 61285,7 \\
\hline & 5 & 26 & 26,7 & 1,1 & 53,3 & 62857,1 \\
\hline & 4 & 30 & 22 & 1,23 & 44 & 64428,6 \\
\hline & 3 & 34 & 17,3 & 1,36 & 34,7 & 66000 \\
\hline & 2 & 36 & 14,9 & 1,64 & 29,8 & 68333,3 \\
\hline & 1 & 37 & 12,4 & 1,92 & 24,9 & 70666,7 \\
\hline & 0 & 39 & 10 & 2,2 & 20 & 73000 \\
\hline \multicolumn{2}{|c|}{ Level } & 2,33 & 2,4 & 3,27 & 2,33 & 6 \\
\hline \multirow{2}{*}{\multicolumn{2}{|c|}{$\begin{array}{l}\text { Weight } \\
\text { Value }\end{array}$}} & 0,75 & 0,25 & 1 & 1 & 1 \\
\hline & & 1,75 & 0,6 & 3,27 & 2,33 & 6 \\
\hline
\end{tabular}

Tabel 7 Matrik Scoring System Perspektif Make

\begin{tabular}{|c|c|c|c|c|c|c|}
\hline \multicolumn{7}{|c|}{ CV. Tuah Bahari } \\
\hline KPI & & M.R.1 & M.R.2 & M.R.3 & M.Re.1 & M.C. 1 \\
\hline \multirow{11}{*}{ Level } & 10 & 0 & 0,67 & 0,084 & 3 & 1000 \\
\hline & 9 & 10 & 0,66 & 0,082 & 4 & 1218,7 \\
\hline & 8 & 20 & 0,64 & 0,080 & 5 & 1437,5 \\
\hline & 7 & 30 & 0,62 & 0,078 & 6 & 1656,2 \\
\hline & 6 & 40 & 0,61 & 0,076 & 7 & 1874,9 \\
\hline & 5 & 50 & 0,59 & 0,074 & 8 & 2093,6 \\
\hline & 4 & 60 & 0,57 & 0,072 & 9 & 2312,4 \\
\hline & 3 & 70 & 0,56 & 0,069 & 10 & 2531,1 \\
\hline & 2 & 80 & 0,44 & 0,055 & 11 & 3441,8 \\
\hline & 1 & 90 & 0,32 & 0,040 & 12 & 4352,6 \\
\hline & 0 & 100 & 0,2 & 0,025 & 13 & 5263,3 \\
\hline \multicolumn{2}{|c|}{ Level } & 10 & 5 & 5 & 10 & 4,71 \\
\hline \multicolumn{2}{|c|}{ Weight } & 0,59 & 0,25 & 0,16 & 1 & 1 \\
\hline \multicolumn{2}{|c|}{ Value } & 5,9 & 1,25 & 0,8 & 10 & 4,71 \\
\hline
\end{tabular}

\begin{tabular}{|c|c|c|c|c|c|c|}
\hline \multicolumn{7}{|c|}{ PT. Nagata Prima Tuna } \\
\hline \multicolumn{1}{|c|}{ KPI No. } & M.R.1 & M.R.2 & M.R.3 & M.Re.1 & M.C.1 \\
\hline \multirow{6}{*}{} & 10 & 0 & 1,14 & 1,14 & 3 & 1500 \\
\cline { 2 - 7 } & 9 & 10 & 1,02 & 0,98 & 4 & 1877,1 \\
\cline { 2 - 7 } & 8 & 20 & 0,91 & 0,82 & 5 & 2254,3 \\
\cline { 2 - 7 } & 7 & 30 & 0,79 & 0,67 & 6 & 2631,4 \\
\cline { 2 - 7 } Level & 6 & 40 & 0,68 & 0,51 & 7 & 3008,5 \\
\cline { 2 - 7 } & 5 & 50 & 0,56 & 0,35 & 8 & 3385,6 \\
\cline { 2 - 7 } & 4 & 60 & 0,45 & 0,20 & 9 & 3762,8 \\
\cline { 2 - 7 } & 3 & 70 & 0,33 & 0,04 & 10 & 4139,9 \\
\cline { 2 - 7 } & 2 & 80 & 0,33 & 0,04 & 11 & 4332,9 \\
\cline { 2 - 7 } & 1 & 90 & 0,31 & 0,04 & 12 & 4525,9 \\
\cline { 2 - 7 } & 0 & 100 & 0,29 & 0,04 & 13 & 4718,9 \\
\hline \multicolumn{2}{|c|}{ Level } & 10 & 2,4 & 2,4 & 10 & 2,47 \\
\hline \multicolumn{2}{|c|}{ Weight } & 0,59 & 0,25 & 0,16 & 1 & 1 \\
\hline \multicolumn{2}{|c|}{ Value } & 5,9 & 0,6 & 0,384 & 10 & 2,47 \\
\hline
\end{tabular}

Pada Tabel 8 dapat dilihat bahwa nilai scoring system perspektif deliver pada CV. Tuah Bahari sangat baik. Semua KPI berada pada katagori hijau (sangat baik). Sementara scoring system perspektif deliver pada PT. Nagata Prima Tuna yang terendah berada pada KPI D.Re.1 dan D.C.1 dengan skor pencapaian sebesar 7,67 dan 7,6. KPI tersebut berada pada kategori kuning namun tetap masih perlu ditingkatkan performansinya.

Pada Tabel 9 dapat dilihat bahwa nilai scoring system perspektif return $\mathrm{CV}$. Tuah Bahari dan PT. Nagata Prima Tuna sangat baik. KPI R.R1 berada pada katagori hijau (sangat baik).

Setelah dilakukan pengukuran performansi supply chain di CV. Tuah Bahari dan PT. Nagata Prima Tuna secara keseluruhan, diperoleh nilai Index Total sebesar 6,29 dan 5,27 pada skala 10 atau 62,9 dan 52,7 pada skala 100. Setelah diperoleh nilai Index Total, langkah selanjutnya adalah memberi penilaian berdasarkan sistem monitoring indikator kinerja.

Berdasarkan Tabel 11, didapatkan bahwa kinerja perusahaan CV. Tuah Bahari dan PT. Nagata Prima Tuna berada pada kategori Average, yang artinya performansi supply chain CV. Tuah Bahari dan PT. Nagata Prima Tuna secara keseluruhan belum mencapai performa yang diharapkan. Untuk meningkatkan performansi, CV. Tuah Bahari harus segera melakukan perbaikan pada KPI P.R.1, S.R.2, S.F.1, dan S.C.1. Sementara PT. Nagata Prima Tuna harus segera melakukan perbaikan pada KPI P.R1, P.A.1, S.R.1, S.R.2, S.Re.1, dan S.F.1. 
Tabel 8 Matrik Scoring System Perspektif Deliver

\begin{tabular}{|c|c|c|c|c|c|c|}
\hline \multicolumn{7}{|c|}{ CV. Tuah Bahari } \\
\hline \multicolumn{2}{|c|}{ KPI No. } & D.R.1 & D.R.2 & D.R.3 & D.Re.1 & D.C. 1 \\
\hline \multirow{11}{*}{ Level } & 10 & 100 & 100 & 5 & 1 & 1500 \\
\hline & 9 & 99 & 99 & 5,04 & 2 & 1600 \\
\hline & 8 & 98 & 98 & 5,08 & 3 & 1700 \\
\hline & 7 & 97 & 97 & 5,12 & 4 & 1800 \\
\hline & 6 & 96 & 96 & 5,16 & 5 & 1900 \\
\hline & 5 & 95 & 95 & 5,2 & 6 & 2000 \\
\hline & 4 & 94 & 94 & 5,24 & 7 & 2100 \\
\hline & 3 & 93 & 93 & 5,29 & 8 & 2200 \\
\hline & 2 & 92 & 92 & 5,86 & 9 & 2300 \\
\hline & 1 & 91 & 91 & 6,43 & 10 & 2400 \\
\hline & 0 & 90 & 90 & 7 & 11 & 2500 \\
\hline \multicolumn{2}{|c|}{ Level } & 10 & 10 & 8,57 & 10 & 10 \\
\hline \multicolumn{2}{|c|}{ Weight } & 0,65 & 0,12 & 0,23 & 1 & 1 \\
\hline \multicolumn{2}{|c|}{ Value } & 6,5 & 1,2 & 1,97 & 10 & 10 \\
\hline
\end{tabular}

\begin{tabular}{|c|c|c|c|c|c|c|}
\hline \multicolumn{7}{|c|}{ PT. Nagata Prima Tuna } \\
\hline \multicolumn{2}{|c|}{ KPI No. } & D.R.1 & D.R.2 & D.R.3 & D.Re.1 & D.C.1 \\
\hline \multirow{6}{*}{ Level } & 10 & 100 & 100 & 20 & 1 & 29178,8 \\
\cline { 2 - 7 } & 9 & 99 & 99 & 21 & 2 & 30310,9 \\
\cline { 2 - 7 } & 8 & 98 & 98 & 22 & 3 & 31443 \\
\cline { 2 - 7 } & 7 & 97 & 97 & 23 & 4 & 32575,2 \\
\cline { 2 - 7 } & 6 & 96 & 96 & 24 & 5 & 33707,3 \\
\cline { 2 - 7 } & 5 & 95 & 95 & 25 & 6 & 34839,4 \\
\cline { 2 - 7 } & 4 & 94 & 94 & 26 & 7 & 35971,5 \\
\cline { 2 - 7 } & 3 & 93 & 93 & 27 & 8 & 37103,6 \\
\cline { 2 - 7 } & 2 & 92 & 92 & 28 & 9 & 38235,8 \\
\cline { 2 - 7 } & 1 & 91 & 91 & 29 & 10 & 39367,9 \\
\cline { 2 - 7 } & 0 & 90 & 90 & 30 & 11 & 40500 \\
\hline \multicolumn{2}{|c|}{ Level } & 10 & 10 & 10 & 7,67 & 7,6 \\
\hline Weight & 0,65 & 0,12 & 0,23 & 1 & 1 \\
\hline \multicolumn{2}{|c|}{ Value } & 6,5 & 1,2 & 2,3 & 7,67 & 7,6 \\
\hline
\end{tabular}

Tabel 9 Matrik Scoring System Perspektif Return

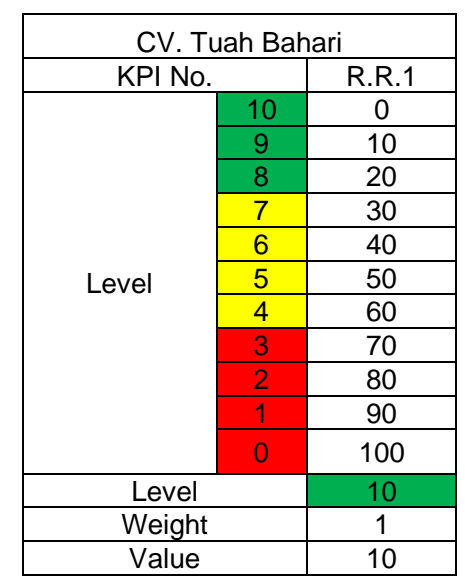

\begin{tabular}{|c|c|c|}
\hline \multicolumn{2}{|c|}{ PT. Nagata Prima Tuna } \\
\hline \multicolumn{2}{|c|}{ KPI No. } & R.R1 \\
\hline \multirow{4}{*}{} & 10 & 0 \\
\cline { 2 - 3 } & 9 & 10 \\
\cline { 2 - 3 } & 8 & 20 \\
\cline { 2 - 3 } & 7 & 30 \\
\cline { 2 - 3 } & 6 & 40 \\
\cline { 2 - 3 } & 5 & 50 \\
\cline { 2 - 3 } & 4 & 60 \\
\cline { 2 - 3 } & 3 & 70 \\
\cline { 2 - 3 } & 2 & 80 \\
\cline { 2 - 3 } & 1 & 90 \\
\cline { 2 - 3 } & 0 & 100 \\
\hline Level & 10 \\
\hline Weight & 1 \\
\hline Value & 10 \\
\hline
\end{tabular}

Tabel 10 Matrik Pengukuran Performansi Supply Chain

\begin{tabular}{|c|c|c|c|c|}
\hline \multicolumn{5}{|c|}{ CV. Tuah Bahari } \\
\hline No & Perspektif & Dimensi & \multicolumn{2}{|c|}{$\mathrm{KPI}$} \\
\hline \multirow[b]{2}{*}{1} & \multirow[b]{2}{*}{ Plan $(4,18)$} & Reability $(3,33)$ & P.R.1 & 3,33 \\
\hline & & $\begin{array}{l}\text { Responsivenees } \\
(5,9)\end{array}$ & P.A.1 & 5,9 \\
\hline \multirow{5}{*}{2} & \multirow{5}{*}{$\begin{array}{c}\text { Source } \\
(4,91)\end{array}$} & \multirow{2}{*}{ Reability $(8,11)$} & S.R.1 & 10 \\
\hline & & & S.R.2 & 2,44 \\
\hline & & $\begin{array}{l}\text { Responsivenees } \\
(4,11)\end{array}$ & S.Re.1 & 4,11 \\
\hline & & flexibility $(2,44)$ & S.F.1 & 2,44 \\
\hline & & Cost $(3,56)$ & S.C. 1 & 3,56 \\
\hline \multirow{5}{*}{3} & \multirow{5}{*}{ Make $(6,47)$} & \multirow{3}{*}{ Reability $(7,95)$} & M.R.1 & 10 \\
\hline & & & M.R.2 & 5 \\
\hline & & & M.R.3 & 5 \\
\hline & & $\begin{array}{l}\text { Responsivenees } \\
\text { (10) }\end{array}$ & M.Re.1 & 10 \\
\hline & & Cost $(4,71)$ & M.C. 1 & 4,71 \\
\hline \multirow{5}{*}{4} & \multirow{5}{*}{$\begin{array}{l}\text { Deliver } \\
(9,79)\end{array}$} & \multirow{3}{*}{ Reability $(9,67)$} & D.R.1 & 10 \\
\hline & & & D.R.2 & 10 \\
\hline & & & D.R.3 & 8,57 \\
\hline & & $\begin{array}{l}\text { Responsivenees } \\
\text { (10) }\end{array}$ & D.Re.1 & 10 \\
\hline & & Cost (10) & D.C. 1 & 10 \\
\hline 5 & Return (10) & Reability (10) & R.R.1 & 10 \\
\hline \multicolumn{5}{|c|}{ Index Total } \\
\hline & & 6,29 & & \\
\hline
\end{tabular}

\begin{tabular}{|c|c|c|c|c|}
\hline \multicolumn{5}{|c|}{ PT. Nagata Prima Tuna } \\
\hline No & Perspektif & Dimensi & \multicolumn{2}{|c|}{$\mathrm{KPI}$} \\
\hline \multirow[b]{2}{*}{1} & \multirow[b]{2}{*}{ Plan $(3,46)$} & Reability $(3,33)$ & P.R.1 & 3,33 \\
\hline & & $\begin{array}{l}\text { Responsivenees } \\
(3,73)\end{array}$ & P.A.1 & 3,73 \\
\hline \multirow{5}{*}{2} & \multirow{5}{*}{$\begin{array}{l}\text { Source } \\
(4,07)\end{array}$} & \multirow{2}{*}{ Reability $(2,35)$} & S.R.1 & 2,33 \\
\hline & & & S.R.2 & 2,4 \\
\hline & & $\begin{array}{l}\text { Responsivenees } \\
(3,27)\end{array}$ & S.Re.1 & 3,27 \\
\hline & & flexibility $(2,33)$ & S.F.1 & 2,33 \\
\hline & & Cost (6) & S.C.1 & 6 \\
\hline \multirow{5}{*}{3} & \multirow{5}{*}{ Make $(4,95)$} & \multirow{3}{*}{ Reability $(6,88)$} & M.R.1 & 10 \\
\hline & & & M.R.2 & 2,4 \\
\hline & & & M.R.3 & 2,4 \\
\hline & & $\begin{array}{l}\text { Responsivenees } \\
\text { (10) }\end{array}$ & M.Re.1 & 10 \\
\hline & & Cost $(2,47)$ & M.C.1 & 2,47 \\
\hline \multirow{5}{*}{4} & \multirow{5}{*}{$\begin{array}{c}\text { Deliver } \\
(8,33)\end{array}$} & \multirow{3}{*}{ Reability (10) } & D.R.1 & 10 \\
\hline & & & D.R.2 & 10 \\
\hline & & & D.R.3 & 10 \\
\hline & & $\begin{array}{l}\text { Responsivenees } \\
(7,67)\end{array}$ & D.Re.1 & 7,67 \\
\hline & & Cost $(7,6)$ & D.C. 1 & 7,6 \\
\hline 5 & Return (10) & Reability (10) & R.R.1 & 10 \\
\hline \multicolumn{5}{|c|}{ Index Total } \\
\hline & & 5,27 & & \\
\hline
\end{tabular}


Tabel 11 Sistem Monitoring Indikator Kinerja

\begin{tabular}{cc}
\hline Sistem Monitoring & Indikator Kinerja \\
\hline$<40$ & Poor \\
$40-50$ & Marginal \\
$50-70$ & Average \\
$70-90$ & Good \\
$>90$ & Exellent \\
\hline
\end{tabular}

\section{PEMBAHASAN}

Pengelolaan supply chain merupakan suatu konsep pendekatan yang tepat untuk mengatasi masalah pemenuhan permintaan konsumen. Waktu penyampaian produk ke konsumen akhir dituntut seefisien mungkin dengan tetap menjaga kualitas produk, jumlah produk dan biaya yang dikeluarkan (Tompodung et al. 2016).

Jika dilihat dari ketepatan waktu, CV. Tuah Bahari masih belum optimal dalam kategori receive product cycle time yaitu waktu yang dibutuhkan dalam menerima ikan tuna dari nelayan. Rata-rata waktu yang dibutuhkan untuk menerima 1 ton ikan tuna dari nelayan adalah 3 hari. Sementara target perusahaan adalah 1.3 ton ikan tuna perhari. PT. Nagata Prima Tuna juga belum optimal dalam kategori receive product cycle time. Rata-rata waktu yang dibutuhkan untuk menerima 1 ton ikan tuna adalah lebih dari 1 hari yaitu 1,3 hari berdasarkan hitungan, sementara target perusahaan adalah 2,3 ton tuna perhari.

Jika dilihat dari biaya, CV. Tuah Bahari dan PT. Nagata Prima Tuna masih belum optimal. Berdasarkan matrik OMAX, CV. Tuah Bahari berada pada kategori merah pada cost to source dan kuning pada cost to make. Sementara PT. Nagata Prima Tuna berada pada kategori kuning pada cost to source dan cost to make pada kategori merah. Hasil tersebut menunjukkan bahwa biaya yang dikeluarkan CV. Tuah Bahari dan PT. Nagata Prima masih tergolong tinggi baik pada pembelian bahan baku maupun biaya produksi.

Aliran produk ikan tuna dinilai belum optimal, karena CV. Tuah Bahari dan PT. Nagata Prima Tuna selalu kekurangan bahan baku ikan tuna. CV. Tuah Bahari hanya sekali mampu memenuhi pasokan ikan tuna pada bulan April 2016, pada bulan April jumlah ikan tuna yang dipasok 41 ton, melebihi target perbulan sebanyak 35 ton. Sementara PT. Nagata Prima Tuna tidak pernah sekalipun mencapai target bahan baku 50 ton ikan tuna perbulan. Menurut Indrajit dan Djokopranoto (2003) dalam Rantung et al. (2016) salah satu faktor kunci untuk mengoptimalkan supply chain dengan menciptakan alur informasi yang bergerak secara mudah dan akurat diantara jaringan atau mata rantai rantai. Aliran informasi dinilai belum optimal pada CV. Tuah Bahari dan PT. Nagata Prima Tuna, dapat dilihat pada Gambar 1 dimana salah satu penyebabnya adalah lemahnya koordinasi antara CV. Tuah Bahari dan PT. Nagata Prima Tuna dengan toke bangku. Sembilan puluh persen ikan tuna dijual ke Medan oleh toke bangku dengan jumlah rata-rata 200 ton perbulan, sementara CV. Tuah Bahari dan PT. Nagata Prima Tuna kekurangan bahan baku ikan tuna.

Hasil ketiga aspek yang diteliti, hanya aliran keuangan yang dinilai sudah optimal. Aliran keuangan mengalir dari pihak eksportir ke PT. Nagata Prima Tuna hanya membutuhkan waktu kurang dari 1 minggu untuk pelunasan pembelian ikan tuna. Uang tersebut langsung dikirim oleh pihak eksportir kepada rekening PT. Nagata Prima Tuna.

Aliran keuangan yang mengalir dari Agen penampung (Jakarta Utara) kepada PT. Nagata Prima Tuna dan dari PT. Era Mandiri Cemerlang ke CV. Tuah Bahari juga lancar dan membutuhkan waktu kurang dari 1 minggu. Sementara aliran keuangan dari CV. Tuah Bahari dan PT. Nagata Prima kepada toke bangku dan nelayan di bayar secara cash.

Berdasarkan hasil perhitungan scoring system dengan menggunakan OMAX pada CV. Tuah Bahari dapat diketahui bahwa terdapat $9 \mathrm{KPI}$ yang masuk dalam kategori hijau, $5 \mathrm{KPI}$ yang masuk dalam kategori kuning, dan $4 \mathrm{KPI}$ yang masuk dalam kategori merah. Sementara pada PT. Nagata Prima Tuna dapat diketahui bahwa terdapat $6 \mathrm{KPI}$ yang masuk dalam kategori hijau, $3 \mathrm{KPI}$ yang masuk dalam kategori kuning, dan $9 \mathrm{KPI}$ yang masuk dalam kategori merah. Untuk KPI yang belum mencapai target, yaitu KPI pada kategori merah dan kuning harus diberi tindakan perbaikan untuk meningkatkan performansi supply chain perusahaan. Namun yang perlu segera mendapatkan prioritas perbaikan adalah KPI pada kategori merah karena nilai pencapaiannya sangat jauh di bawah target.

Penelitian ini dapat dibandingkan dengan penelitian dari Hanugrani et al. (2011) tentang pengukuran performansi supply chain 
dengan menggunakan Supply Chain Operation Reference (SCOR) berbasis Analytical Hierarchy Process (AHP) dan Objective Matrix (OMAX). Hasil dari penelitian menunjukkan bahwa nilai pencapaian performansi supply chain perusahaan secara keseluruhan adalah sebesar 7,85 (78,5 pada skala 100). Dengan melakukan pembobotan menggunakan AHP dan perhitungan scoring system menggunakan OMAX, diketahui 4 indikator kinerja supply chain yang perlu segera mendapatkan tindakan perbaikan, yaitu penyimpangan peramalan permintaan, jumlah pemasokan bahan baku, ketidaksesuaian bahan baku dengan spesifikasi, dan jumlah komplain dari konsumen.

Hasil dari $4 \mathrm{KPI}$ yang mendapat kategori merah pada CV. Tuah Bahari, 3 diantaranya adalah katagori source yaitu S.R.2 (Pemenuhan bahan baku), S.F.1 (Supply chain flexibility and adaptability) dan S.C.1 (Cost to source). Sementara dari 5 katagori kuning yang didapatkan CV. Tuah Bahari 4 diantaranya sangat berhubungan dengan bahan baku tuna yang tersedia (source). Ke 4 katagori tersebut adalah P.A.1 (Cash to cash cycle time), S.Re.1 (Receive product cycle time), M.R.2 (Jumlah total produksi) dan M.R.3 (Jumlah Produksi karyawan/Jam).

Hasil dari 9 KPI yang mendapat katagori merah pada PT. Nagata Prima Tuna, 4 diantaranya adalah katagori source yaitu S.R.1 (bahan baku yang kurang bagus), S.R.2 (pemenuhan bahan baku), S.F.1 (Supply chain flexibility and adaptability) dan S.C.1 (Cost to source). 3 Katagori lainnya yang mendapat kategori merah juga mempunyai hubungan yang sangat erat dengan perspektif source yaitu P.A.1 (Cash to cash cycle time), M.R.2 (Jumlah total produksi) dan M.R.3 (Jumlah Produksi karyawan/Jam).

Kekurangan bahan baku ikan tuna adalah penyebab utama yang membuat performa (kinerja) CV. Tuah Bahari dan PT. Nagata Prima Tuna rendah. Kekurangan bahan baku juga ikut membuat performa perspektif lainnya ikut rendah, seperti jumlah produksi ikan tuna yang ikut rendah karena kekurangan bahan baku. Kekurangan bahan baku tersebut harus segera diatasi oleh CV. Tuah Bahari dan PT. Nagata Prima Tuna.

\section{KESIMPULAN}

Kinerja CV. Tuah Bahari dan PT. Nagata Prima Tuna belum optimal. Aliran fisik ikan tuna yang belum optimal dilihat dari ketepatan waktu, biaya yang dikeluarkan dan jumlah produk yang dihasilkan. Sementara aliran informasi yang belum optimal dilihat dari lemahnya koordinasi kedua perusahaan dengan toke bangku yang menyebabkan toke bangku menjual 90\% ikan tuna ke Medan. Hanya aliran keuangan yang sudah optimal dilihat dari waktu pembayaran.

Hasil pengukuran efesiensi kinerja CV. Tuah Bahari terdapat $4 \mathrm{KPI}$ berada pada kategori Poor sementara pada PT Nagata Prima Tuna terdapat $9 \mathrm{KPI}$ berada pada kategori Poor yang segera harus segera mendapat tindakan perbaikan. Sementara total nilai performansi kedua perusahaan berada pada katagori Average, dengan nilai Index Total CV. Tuah Bahari 62.9 dan PT. Nagata Prima Tuna 52.7.

\section{SARAN}

Pihak perusahaan CV. Tuah Bahari maupun PT. Nagata Prima Tuna harus lebih aktif dalam membangun komunikasi dengan toke bangku dan menawarkan kerja sama dengan membentuk kemitraan, ataupun dapat membentuk Memorandum of Understanding (MOU) antara perusahaan dengan toke bang$\mathrm{ku}$, agar toke bangku tidak membawa ikan tuna hasil tangkapan ke Medan. Kekurangan bahan baku yang terjadi disebabkan oleh banyaknya toke bangku yang menjual ikan tuna hasil tangkapan ke Medan.

Perusahaan harus melakukan perbaikan indikator yang memiliki kinerja rendah sehingga tingkat pencapaian terhadap target perusahaan dapat ditingkatkan lagi. Perusahaan harus tetap mempertahankan KPI yang memiliki kinerja baik.

\section{UCAPAN TERIMA KASIH}

Penulis mengucapkan terima kasih kepada kepada CV. Tuah Bahari dan PT. Nagata Prima Tuna yang telah memberikan izin dan informasi kepada penulis.

\section{DAFTAR PUSTAKA}

Adianto, Saryatmo MA, Gunawan AS. 2014. Analisis Pengukuran Kinerja Perusahaan dengan Metode Performance Prism dan Scoring Objective Matrix (OMAX) pada PT. Bpas. Sinergi. 18 (2): 61-70.

Avianda D, Yunita Y, Yuniar. 2014. Strategi Peningkatan Produktivitas di Lantai Produksi Menggunakan Metode 
Objective Matrix (OMAX). Jurnal Online Institut Teknologi Nasional. 4 (1): 202-213.

Batubara SC, Maarif MS, Marimin, Irianto HE. 2017. Model Manajemen Rantai Pasok Industri Perikanan Tangkap Berkelanjutan. Marine Fisheries. 8(2): 137-148.

Budiman E.V. 2013. Evaluasi Kinerja Supply Chain pada UD. Maju Jaya di Desa Tiwoho Kabupaten Minahasa Utara. Jurnal EMBA. 1(4): 443-452.

Dania WAP, Santoso I, Permatasari R. 2012. Analisis Pengukuran Kinerja Korporasi Menggunakan Metode Performance Prism (Studi Kasus di PT Inti Luhur Fuja Abadi, Pasuruan). Jurnal Teknologi Pertanian. 13(1): 67-77.

Darojat, Yunitasari. 2017. Pengukuran Performansi Perusahaan dengan Menggunakan Metode Supply Chain Operation Reference (SCOR). Seminar dan Konferensi Nasional IDEC 2017 8-9 Mei 2017.

Dinata H, Suryani E, Hendrawan RA. 2014. Peningkatan Kinerja Sistem Rantai Pasok di Industri Perikanan untuk Ketahanan Pangan. Jurnal Sistem Informasi. 5(2): 86-94.

Hanugrani N, Setyanto NW, Efranto RY. 2011. Pengukuran Performansi Supply Chain dengan Menggunakan Supply Chain Operation Reference (SCOR) Berbasis Analytical Hierarchy Process (AHP) dan Objective Matrix (OMAX). Jurnal Rekayasa dan Manajemen Sistem Industri. 1(1): 163-172.

Harisnanda F, Amaly I, Gusman AM, Febriani F, Zamer A, Elisya A. 2012. Analisis Sistem Rantai Pasok Minyak. Jurnal Optimasi Sistem Industri. 11(1): 221224.

Jati AK, Nurani TW, Iskandar BH. 2014. Sistem Rantai Pasok Tuna Loin di Perairan Maluku. Marine Fisheries. 5 (2) : 171-180.

Lestiani ME. (2011). Faktor-Faktor Dominan Promosi yang Mempengaruhi Motivasi Konsumen dalam Membeli Suatu Produk dengan Menggunakan Metode AHP. INDEPT. 1: 15-20.
Mutakin A, Hubeis M. 2011. Pengukuran Kinerja Manajemen Rantai Pasokan dengan SCOR Model 9.0 (Studi Kasus di PT Indocement Tunggal Prakarsa Tbk). Jurnal Manajemen dan Organisasi. 3(2): 89-103.

Ndiba TAF, Wullur M, Tumade P. 2016. Evaluasi Kinerja Rantai Pasok Komoditas Cengkeh (Studi pada Desa Lalumpe Kabupaten Minahasa). Jurnal EMBA. 4(1): 153-164.

Nurani TW, Ardani, Lubis E. 2014. Sasaran Strategis Pengembangan Model Kluster Industri Perikanan Tangkap. Marine Fisheries. 5(2): 109-118.

Pasmawati Y, Kusmindari Ch. D. 2013. Analisa Dan Aplikasi Metode Zero One Dan Analitycal Hierarchy Process (AHP) Dalam Perancangan Becak. Jurnal IImiah TEKNO. 10(1): 01-12.

Pranoto YA, Muslim MA, Hasanah RN. 2013. Rancang Bangun dan Analisis Decision Support System Menggunakan Metode Analytical Hierarchy Process untuk Penilaian Kinerja Karyawan. Jurnal EECCIS. 7(1): 91-96.

Rakhman A, Machfud, Arkeman Y. 2018. Kinerja Manajemen Rantai Pasok dengan Menggunakan Pendekatan Metode Supply Chain Operation Reference (SCOR). Jurnal Aplikasi Bisnis dan Manajemen (JABM). 4(1): 106118.

Rantung ML, Adolfina, Wenas RS. 2016. Analisis Kinerja Rantai Pasok Komoditas Kacang Tanah di Pasar Tradisional Beriman Kota Tomohon. Jurnal EMBA. 4(2): 849-858.

Ruteri JM, Qi Yu. 2009. Supply Chain Management and Challenges Facing the Food Industry Sector in Tanzania. International Journal of Business and Management. 4(12).

Sari SW, Nurmalina R, Setiawan B. 2014. Efesiensi Kinerja Rantai Pasok Ikan Lele di Indramayu Jawa barat. Jurnal Manajemen \& Agribisnis. 11(1): 1223. 
Subroto AM, Kawet L, Sumarauw J. 2015. Evaluasi Kinerja Supply Chain Manajemen Pada Produksi Beras di Desa Panasen Kecamatan Kakas. Jurnal EMBA. 3(1): 653-662.

Sufa MF, Wigaringtyas LD, Munawir H. 2016. Strategi Peningkatan Kinerja Rantai Pasok UKM Batik dengan Supply Chain Operation Reference (SCOR). IENACO (Industrial Engineering $\mathrm{Na}$ tional Conference) 23 Maret 2016.

Tompodung E, Worang FG, Roring F. 2016. Analisis Rantai Pasok (Supply Chain) Ikan Mujair di Kecamatan Eris Kabu- paten Minahasa. Jurnal EMBA. 4(4): 279-290.

Walangare D, Delima R, Restyandito. 2012. Sistem Prediksi Pertandingan Sepak Bola dengan Metode Analytical Hierarchy Process (AHP). Informatika. 8(2): 181-188.

Wuwung SC. 2013. Manajemen Rantai Pasokan Produk Cengkeh Pada Desa Wawona Minahasa Selatan. Jurnal EMBA. 1(3): 230-238.

Yusuf M. 2014. Metode Penelitian: Kuantitatif, Kualitatif, dan Penelitian Gabungan. Jakarta: Kencana. 